condition imposed in paragraph $\left(r_{4}\right)$, which I quote, deserves a wider publicity.

(14) It should be noted that grants to research workers will be subject to the following conditions [among others]:-

"The results of the investigation as obtained from time to time shall, in the first place, be communicated to the Committee of Council, who, after consultation with the bodies and persons who have co-operated in the conduet and maintenance of the research, shall determine in the national interest whether, and if so co what extent and under. what conditions, the results shall be made available.

"The Committee of Council reserve the right to determine, after consultation with the bodies and persons who have co-operated in the conduct and maintenance of the research; whether, and if so to what extent and in what proportions, the Committee of Council and those bodies and persons shall secure to themselves by patent, designs or otherwise, the ownership of the results of the research and any benefits and profits arising therefrom.

"It is not expected that results of direct technical value will often be obtained from research undertaken by a student in training, and the conditions stated above: are not, therefore, attached to a grant to a stivdent. But the professor and student will be asked, should results apparently of commercial value be produced, to consult the Department before taking any action to make the results public, or to communicate them to an industrial firm or other body for exploitation."

I sincerely trust that scientific investigators, whether professors or students, will read, mark, and inwardly digest paragraph ( $\left.\mathrm{s}_{4}\right)$, and think twice before they accept any grant from the Department of Scientific and Industrial Research. They have the right to know who is responsible for the imposition of this condition.

FREDERICK SODDY.

\section{THE SUGAR INDUSTRY AFTER} THE WAR.

$\mathrm{U}$ NDER the above title, Mr. T. H. P. Heriot, the lecturer on sugar manufacture at the Royal Technical College, Glasgow, has communicated a paper to the Royal Philosophical Society of Glasgow which has recently been published in its Proceedings. Since its appearance the subject has occupied the attention of the Royal Society of Arts, and the issue of the journal of the society for June I4 contains an interesting paper by $\mathrm{Mr}$. George Martineau, which traverses much the same ground as that of Mr. Heriot and arrives independently at the same conclusions. The subject is so important at the present juncture, and our position with respect to it, in view of our prospective relations with our enemies, so serious, that no excuse is needed for referring to it. The general course of the development of the sugar industry is too well known to require any detailed description. Both authors deal with it in the introduction to their papers at just sufficient length to render the nature of their arguments and the conclusions to which they arrive intelligible and obvious to their readers.

Originally, all the sugar consumed in this country, and in Europe generally, was made from the sugarcane, and most of it was imported from the West Indies. It was known, however, so far back as NO. 2540 , VOL. IOI] the middle of the eighteenth century, that the particular kind of sugar - sucrose - with which we are now concerned existed in other plants than the sugar-cane. In I747 the chemist Marggraf pointed out that it was present in the beetroot, then being cultivated on an extensive scale in Silesia as a forage crop, and his pupil, Achard, a Frenchman who had settled in Germany, grew the root on his estate, and set up a small manufactory for extracting sugar from it. The success of this enterprise induced King Frederick William of Prussia, in 1801 , to supply funds for the creation of beetroot-sugar factories. The industry may be said; therefore, to take its rise from the beginning of the nineteenth century

The Continental disturbances of that time, combined with our maritime supremacy and the effectiveness of our blockade, especially of the French ports, gave a great impetus to the development of beetroot-sugar manufacture. Napoleon, with characteristic sagacity, quickly. saw in the beetroot a method of countering our blockade, at least so far as regarded the import of sugar. By his orders tens of thousands of acres of French soil were planted with beetroot, and schools of instruction in the art of cultivating it and in the methods of sugar-making were founded by his direction. Before Waterloo ended his career the beetroot-sugar industry of the Continent had been firmly established both in France and in Germany, and to that extent the future welfare of our West Indian possessions was, as Napoleon clearly foresaw, seriously jeopardised.

The creation of the beetroot-sugar industry was due entirely, in the first instance, to the exertions of men of science who had no practical acquaintance with the art of sugar manufacture. Its development has been largely owing to their labours. They have studied the mode of growth of the root and the conditions under which the sugar is secreted, and they have thereby succeeded in greatly increasing the sugar content. By careful and intefligent investigation they have, enormously improved the methods of sugar extraction and subsequent treatment. They have brought chemical knowledge and skill to bear on the improvement of the analysis of saccharine materials and on the elucidation of many problems of a chemioal nature connected with the industry. There is probably no branch of technology that could be named in which science has been more successfully applied than in the creation and development of the beetroot-sugar industry: On the other hand, science, in times past, had little to do with the sugar-cane industry; and so long as the West Indian planters could count upon the enormous profits that they formerly enjoyed, they had little or no inducement to think of science in connection with it.

But it would be untrue to allege that the planters of these latter days have been wholly oblivious te the bearing of science upon their industry. They could not be altogether unmindful of what it had done for their rivals, nor without hope that it might be serviceable in their own case, and, as a matter of fact, various attempts 
have been made by them to help themselves by the aid of science. But they suffered under one great disadvantage as compared with European producers. Whereas Continental Governments, and especially that of Germany, fostered the industry and afforded it financial support, favouring it in a variety of ways by legislative action, the West Indian planters were left, to a large extent, to shift for themselves. Few Colonial Ministers have had the wisdom and foresight of Mr. Joseph Chamberlain. In the face of a bountyfed system, the West Indian planters naturally lost heart, and many sugar estates went out of cultivation; other planters, owing to lack of capital and consequent inability to provide themselves with modern machinery, were brought almost to the verge of ruin. Parliament, under the influence of a fiscal policy which had no real appreciation of Imperial needs, turned a deaf ear to their complaints. It was cold comfort to be told that they were the victims of economic and industrial progress, and of the changing conditions of social development. The masses were so enamoured of the idea of a free breakfast table that they continually returned to power the politicians who misled them with that specious cry.

In the meantime, Germany was steadily maturing her plans to secure world-wide power. Her manufacturers were paid a bounty by their Government to enable them to export sugar at a lower price than the cost of production in the hope of finally ruining the Colonial planter. In 1884 German beet-sugar was first "dumped" in this country. It was useless to point out the real meaning of this action and what the inevitable consequence would be. As Mr. Heriot says, "Great Britain looked only at the immediate advantage of cheap sugar, and cared nothing about the future."

We have now had a rude awakening. It is true that the Brussels Convention of I9OI-2 abolished bounties on beet-sugar by international agreement. But by that time the mischief had been done, and we had become practically dependent on Continental sugar. Germany could well afford to sign the agreement. She fiad largely achieved her purpose. In the year before the outbreak of the war we imported nearly two million tons of sugar, of which less than 4 per cent. was British cane-sugar. Vested interests had meanwhile grown up in this country and had acquired a certain amount of political influence, which a democratic Government was powerless to withstand. What we have suffered from this condition of things scarcely needs to be stated. We have been compelled to transfer our custom, and still to assist, at a heavy cost to ourselves, in the production of sugar elsewhere than within the British Empire. The Colonial industry has, no doubt, slightly increased its production during the war, in spite of many difficulties, and we have rewarded its efforts by taxing it on excess profits.

The whole position in regard to the future of British sugar production needs to be reviewed. The Empire is certainly capable of making all, and NO. 2540 , VOL. IOI] more than all, the sugar it requires. Sugar is, and must continue to be, partly a tropical production and partly home-grown. The sugar-cane can only be grown in the tropics and with the aid of coloured labour. In 1915 the West India Committee ascertained that certain of our Colonies and Dependencies, which now collectively produce about 880,000 tons of cane-sugar annually, could produce $4,000,000$ tons if all the land suitable for the growth of the sugar-cane were cultivated. And this estimate did not include India, Egypt, and the captured German colonies.

The sugar-beet succeeds best in temperate climates, where white labour is available. But Canada is, at present, the only portion of the Empire where the beet-sugar industry has been established, although it has been conclusively demonstrated that the sugar-beet will flourish in Great Britain, in Ireland, in South Africa, and in certain districts of Australia. Up to the present no very serious attempt has been made to introduce its cultivation into England. The Cantley scheme was a financial failure, as it depended on local farmers. Another attempt is now being made at Kelham, in Nottinghamshirt, under other conditions, and the Government has advanced money for the purchase of 5600 acres of land, which seems almost insignificant when compared with the 70,000 acres which Napoleon, in 1811 , ordeted to be planted. But everything has a beginning and we must "wait and see."

It is abundantly clear that there is an ample sufficiency of land within the Empire to supply the world with sugar if the industry were properly organised, and reasonable steps taken to ensure the supply of labour and to attract capital. As regards the tropical production of sugar, more might be done to tap the immense reservoir of labour which exists in India. Home-grown sugar can, probably, only be produced at a higher cost, but the community would gain in other ways by the establishment of a large and important industry producing many valuable by-products, and requiring much machinery and agricultural implements.

To a large extent the problem is a question of tariffs, and its satisfactory solution can be settled only by boldly facing this issue. The country must make up its mind that the era of the cheap sugar of pre-war days is at an end. People who have found it no great hardship to pay $5 \frac{1}{2} d$. per $1 \mathrm{~b}$. for their sugar can surely be induced to pay at least half that sum, exclusive of duty, if they and their successors are assured of a continuous supply produced within the Empire.

The British Empire Producers' Organisation, which was founded in 1915 to encourage the prodúction of foodstuffs, raw materials, and manufactured articles within the Empire, and for the welfare of the Empire as a whole, has dealt with this matter of tariffs, and its proposals include the following :-

(I) That Empire sugar be granted preferential treatment to the extent of 50 per cent. of any tariff that may be in force. This means a reduction of the duty by $\frac{1}{2} d$. per $1 \mathrm{~b}$. 
(2) That sugar produced by our Allies be granted preferential treatment to the extent of $12 \frac{1}{2}$ per cent. on the tariff in force. This corresponds with a reduction of the duty by $\frac{1}{8} d$. per $1 b$.

(3) That sugar produced by neutral countries should pay the full tariff without any reduction.

As regards home-grown sugar the Organisation recognises that some degree of protection will be ahsolutely necessary if capital is to be attracted to the new industry, and it suggests that "the difference between excise on home-grown beetsugar and the duty on Empire-grown cane-sugar shall be $2 l$. os. $8 d$. per ton until the crop of homegrown sugar reaches 50 ,ooo tons per annum, after which such advantage would cease."

These proposals will doubtless be fiercely opposed by all to whom the word "Protection " is anathema. But the events of the time, and the chastening influence of the conditions which have been forced upon us by the Central Powers in the effort by the most powerful of them to secure the domination of the world, have profoundly modified our views on many matters. The Government has now agreed to the principles of Imperial preference, and the policy of preferential treatment of our Allies has been embodied in the resolutions of the Paris Economic Conference.

In regard to tariffs the matter now resolves itself into a question of details, and if the nation is determined, as it no doubt is, that the disadvantage under which it has suffered shall never again arise, but that the machinations of our arch-enemy shall be effectually checkmated, once and for ever, there should be little or no difficulty in arriving at a satisfactory adjustment.

T. E. THORPE.

THE MINERAL WEALTH OF GERMANY. THE Fortnightly Review for June contains an 1 interesting article by "Politicus" on "The Natural Wealth of Germany," in which particular stress is laid upon the immense value of the asset represented by that country's mineral possessions. These are tolerably accurately known, because in Germany the State owns the minerals and has therefore taken good care to have a complete and scientific inventory made of its mineral resources. The facts as to Germany's mineral riches are thus readily accessible, and ample statistical information is available on the subject. Taking the three undoubtedly most important of Germany's mineral products, namely, coal, iron-ore, and potash salts, the author of the article in question arrives at the startling conclusion that the value of these is close upon 240,000 millions sterling, out of which coal alone represents 89 per cent. A German poet has long ago warned the world that no prudent fighter underrates his foe, but it is perhaps almost as grave a blunder to overestimate his powers, and there is no difficulty in showing that this is what "Politicus" has done to an enormous extent.

It will be easiest to commence with coal, this being, as stated, by far the most important factor, whilst abundant statistics are available for discuss- ing the question. "Politicus" takes the report submitted to the International Geological Congress in 1913 , which gave the coal resources of Germany at about 400,000 million tons. He says simply that "at the very low average price of ros. per ton at the pit's mouth" this coal is worth more than 200,000 millions sterling. He forgets, apparently, that this coal is not at the pit's mouth-it is deep within the bowels of the earth. The value of ros. per ton at the pit's mouth may be readily accepted as a fair figure, but this is assuredly not the value of the coal in its unsevered condition. In a recent paper on the subject the writer of the present article showed that the value of coal at the pit's mouth in Great Britain amounted to about ros. per ton in $\mathrm{r}^{\mathrm{I}} 3$, and that this price was made up of :Royalty $5^{\circ} 35$ per cent., wages $62^{*} 55$ per cent., materials 16.45 per cent., administration 7 per cent., and interest and profit $8 \cdot 6_{5}$ per cent. It is surely obvious that it is only the first item which represents the value of the coal as it lies in the ground, and that out of the value of ros. at the pit's mouth $9 s, 6 d$. represents the cost of getting and raising it, so that its real value is only the balance of $6 d$. Certain American figures also quoted by the author of the article show that the royalty value of the coal--that is, the value of the coal as it lies in the seam-is less than 4 per cent. of its cost at the pit's mouth in the United States, so that the figure of 5 per cent. of the value at the surface here adopted may be considered to represent very closely the general value and can be applied to the German conditions without much risk of error. Hence, so far, the figure given by "Politicus" would appear to be twenty times too great, and his 200,000 millions would be reduced to ro, ooo millions.

Even this latter figure is, however, a great overestimate, and that for a reason that "Politicus" has also overlooked. It has been seen that coal in the unsevered condition is worth $6 d$. per ton, but this $6 d$. is realisable only as and when the coal is won. A ton of coal that is to be won a century from now is worth to-day, not $6 d$., but only $0^{\circ} 0456 d$., or less than the twentieth part of a penny, allowing interest at 5 per cent. This quite obvious consideration, that a sum of money, receivable at a distant date, is worth to-day only the amount which, if allowed to accumulate at interest, would produce the sum in question, must profoundly influence the present value of coal to be won at a remote date, but it has been entirely omitted from the calculation. It is true that it is only possible to compute the present value of Germany's coal reserves by making a series of assumptions, yet by means of these we are able to determine, at any rate, the order of magnitude of the figures involved. In I9I3, the coal production of Germany was about ${ }_{50}$ million tons; if it be assumed that this increases by $5^{\circ}$ million tons annually, the production in a century would be at the rate of $5^{1} 5^{\circ}$ million tons per year, and the total quantity worked during the century would be 265 , 000 million tons, or more than half the known coal resources of the country. No one can pos-

NO. 2540 , VOL. IOI] 